\title{
Rhodococcus chubuensis Tsukamura 1982 Is a Later Subjective Synonym of Gordona sputi (Tsukamura 1978) Stackebrandt 1989 comb. nov.
}

\author{
P. RIEGEL, ${ }^{*}$ M. V. KAMNE-FOTSO, D. DE BRIEL, G. PRÉVOST, F. JEHL, \\ Y. PIÉMONT, AND H. MONTEIL \\ Institut de Bactériologie de la Faculté de Médecine, Université Louis-Pasteur, \\ 67000 Strasbourg, France
}

\begin{abstract}
The genus Gordona was proposed by Tsukamura in 1971 (M. Tsukamura, J. Gen. Microbiol. 68:15-24, 1971) and was revived in 1988 by Stackebrandt et al. (E. Stackebrandt, J. Smida, and M. D. Collins, J. Gen. Appl. Microbiol. 34:341-348, 1988) to accommodate Rhodococcus species containing mycolic acids with 48 to 66 carbon atoms and MK-9 $\left(\mathrm{H}_{2}\right)$ as the predominant menaquinone type. On the basis of mycolic acid composition as determined by high-performance liquid chromatography, DNA-DNA similarity data (S1 nuclease procedure), and the rRNA gene restriction patterns of the type strains, we propose that Rhodococcus chubuensis Tsukamura 1982 is a subjective synonym of Gordona sputi (Tsukamura 1978) Stackebrandt 1989 comb. nov. We found that $R$. chubuensis type strain ATCC 33609, and $G$. sputi type strain ATCC 29627 exhibit identical mycolic acid profiles, 97\% DNA relatedness (difference in thermal denaturation midpoints, $1.0^{\circ} \mathrm{C}$ ), and similar ribotypes after $P v u I I$ endonuclease digestion. Thus, as defined by the type strains and considering the priority of the name $G$. sputi, these two species should be regarded as a single species named Gordona sputi; an emended description of this taxon is given.
\end{abstract}

The genus Gordona, with the species Gordona rubra, Gordona terrae, and Gordona bronchialis, was proposed by Tsukamura in 1971 for coryneform bacteria isolated from sputa of patients with pulmonary disease and from soil (17). This genus was distinguished from rapidly growing mycobacteria mainly on the basis of its slight acid fastness and the absence of arylsulfatase and from nocardiae on the basis of a positive nitrate reduction reaction and the absence of mycelium. In 1977 Goodfellow and Alderson delineated by numerical taxonomy the genus Rhodococcus for strains previously placed in the species Mycobacterium rhodochrous and the "rhodochrous complex," including members of the genus Gordona (5). However, additional studies revealed that the genus Rhodococcus was heterogeneous. The three Rhodococcus species originally assigned to the genus Gordona were found to contain mycolic acids with 48 to 66 carbon atoms and MK-9 $\left(\mathrm{H}_{2}\right)$ as the predominant menaquinone type, which differentiated these organisms from the other Rhodococcus species studied $(4,15)$. In 1988 Stackebrandt et al. revived the genus Gordona, with the three previously described species, on the basis of $16 \mathrm{~S}$ rRNA homology results and, in addition, included the species Rhodococcus sputi in this revived genus $(13,14)$. Addenda concerning the species Gordona sputi were published by Tsukamura in 1991; these addenda contained mycolic acid and menaquinone composition data for this organism, which confirmed its status (20).

Rhodococcus chubuensis was described in 1982 by Tsukamura in a numerical analysis study of the taxonomy of nocardiae and rhodococci isolated from human specimens (19). This taxon was included in the genus Rhodococcus and was differentiated from other species solely on the basis of morphological and biochemical properties. Although no chemotaxonomic or genomic studies were performed to verify its taxonomical

\footnotetext{
* Corresponding author. Mailing address: Institut de Bactériologie de la Faculté de Médecine, 3 rue Koeberlé, F-67000 Strasbourg, France. Phone: 33883606 22. Fax: 33.88.25.11.13.
}

status, $R$. chubuensis was subsequently validated as a new species in 1983, with strain E 6324 (= ATCC 33609) as the type strain $(8,10)$. Because of its questionable status, in Bergey's Manual of Systematic Bacteriology Goodfellow considered $R$. chubuensis a species incertae sedis of the genus Rhodococcus (4). Moreover, in 1986 Tomiyasu and Yano (15) found by using gas-liquid chromatography mycolic acids with 55 to 65 carbon atoms in a strain of $R$. chubuensis; this is a characteristic of the genus Gordona. Nevertheless, in 1992 R. chubuensis was included in an emended version of the Approved Lists of Bacterial Names (11).

This situation led us to reinvestigate the taxonomic position of this species. In this study we determined that $R$. chubuensis and $G$. sputi are synonyms on the basis of mycolic acid composition data, DNA-DNA similarity data, and the rRNA gene restriction patterns of the type strains.

\section{MATERIALS AND METHODS}

Bacterial strains. For $R$. chubuensis, we used only type strain ATCC 33609 (provided by the American Type Culture Collection) since very few $R$. chubuensis strains are available. Reference strains $G$. sputi ATCC $29627^{\mathrm{T}}$ (T = type strain), $G$. bronchialis ATCC $25592^{\mathrm{T}}$, and Rhodococcus rhodochrous ATCC $13808^{\mathrm{T}}$ were also obtained directly from the American Type Culture Collection, and reference strains Gordona rubropertincta ATCC 25593, G. terrae ATCC $25594^{\mathrm{T}}$, and $G$. sputi $1834-89$ were kindly provided by P. Boiron, Institut Pasteur, Paris, France.

Growth conditions and biochemical tests. Bacteria were grown aerobically at 30 and $37^{\circ} \mathrm{C}$ on Mueller-Hinton agar and on Coletsos medium. Utilization of citrate, benzoate, inositol, mannitol, L-rhamnose, sorbitol, 2,3-butanediol, monoethanolamine, and $n$-butanol was determined by using media prepared as described by Tsukamura (16). Urease production was tested in Christensen's medium, and nitrate reductase production was tested by using a brain heart broth supplemented with $2 \mathrm{~g}$ of $\mathrm{NaNO}_{3}$ per liter. Enzymatic activities were examined by using 

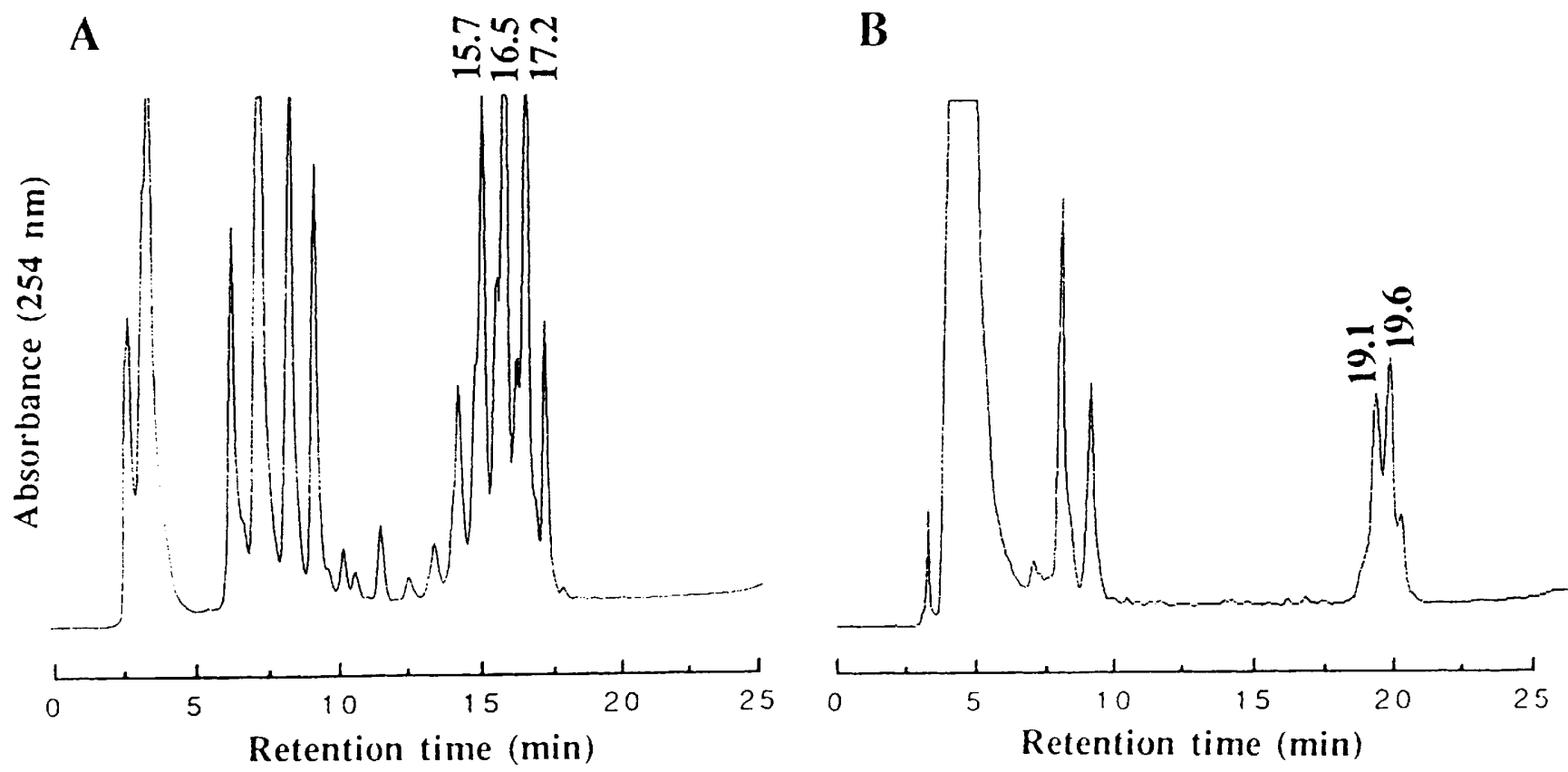

C

D
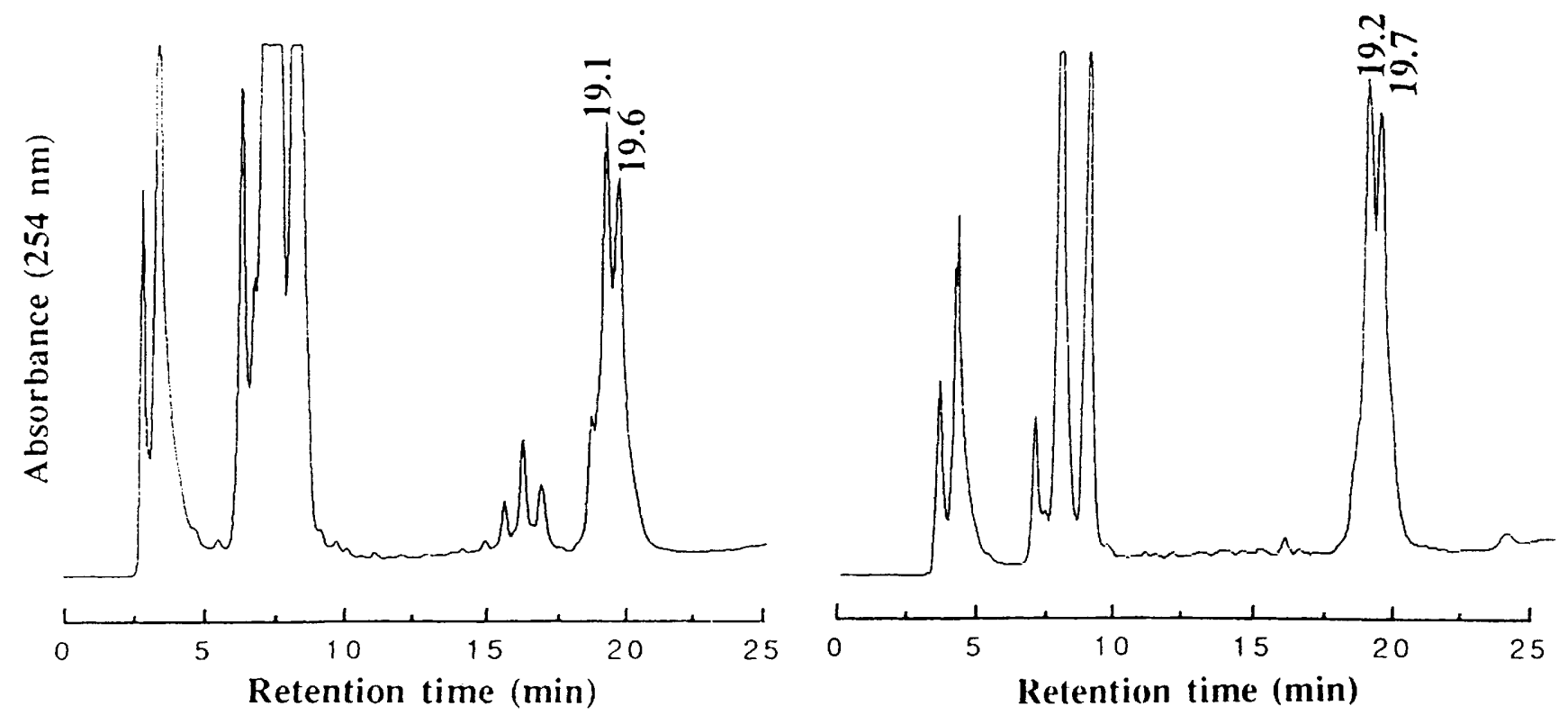

FIG. 1. HPLC patterns of $p$-bromophenacyl esters of mycolic acids from R. rhodochrous ATCC $13808^{\mathrm{T}}$ (A), G. sputi ATCC 29627 ${ }^{\mathrm{T}}$ (B), G. bronchialis ATCC $25592^{\mathrm{T}}$ (C), and $R$. chubuensis ATCC $33609^{\mathrm{T}}$ (D).

the API-ZYM system according to the instructions of the manufacturer (bioMérieux, Marcy l'Etoile, France).

Mycolic acid analysis. Reversed-phase high-performance liquid chromatography (HPLC) was performed to determine mycolic acid contents. Saponification, derivatization, and chromatographic separation were carried out by using the procedure described for the analysis of rhodococcus species in a previous report (3).

DNA-DNA hybridization. DNA was extracted and purified as described previously (12). DNA from $R$. chubuensis ATCC $33609^{\mathrm{T}}$ was labeled by nick translation with $\left[{ }^{3} \mathrm{H}\right] \mathrm{dCTP}$ (Amersham International, Amersham, United Kingdom), using a commercial kit (Gibco Bethesda Research Laboratories). Duplicate hybridization experiments were performed at $65^{\circ} \mathrm{C}$ for $16 \mathrm{~h}$ in $0.42 \mathrm{M} \mathrm{NaCl}$ by the $\mathrm{S} 1$ nuclease-trichloroacetic acid method (7). The denaturation temperature at which $50 \%$ of the reassociated DNA became hydrolyzable by $\mathrm{S} 1$ nuclease was determined in $0.2 \mathrm{M} \mathrm{NaCl}$ by the method of Crosa et al. (2). $\Delta T_{m}$ was the difference between the denaturation temperature of a homoduplex (in a homologous reaction) and the denaturation temperature of a heteroduplex (in a heterologous reaction).

Ribotyping. DNA was digested with restriction endonuclease PvuII. DNA fragments were separated by agarose gel 
TABLE 1. Levels of DNA relatedness between $R$. chubuensis ATCC $33609^{\mathrm{T}}$ and Gordona reference strains

\begin{tabular}{|c|c|}
\hline Source of unlabeled DNA & $\begin{array}{c}\% \text { Relative } \\
\text { reassociation with } \\
\text { strain ATCC } \\
33609^{\mathrm{T}} \text { at } 65^{\circ} \mathrm{C}\end{array}$ \\
\hline R. chubuensis ATCC $33609^{\mathrm{T}}$. & 100 \\
\hline G. sputi ATCC $29627^{\mathrm{T}} \ldots \ldots \ldots \ldots$. & $97(1.0)^{a}$ \\
\hline 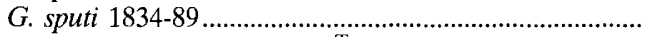 & $100(1.0)$ \\
\hline 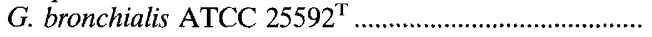 & 7 \\
\hline 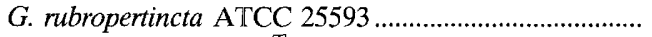 & 7 \\
\hline 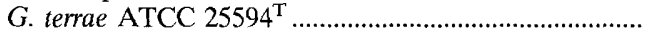 & 9 \\
\hline
\end{tabular}

${ }^{a}$ The values in parentheses are $\Delta T_{m}$ values (in degrees Celsius).

electrophoresis, transferred to a nylon membrane, and hybridized with $5^{\prime}-{ }^{32} \mathrm{P}$-labeled Escherichia coli $16 \mathrm{~S}+23 \mathrm{~S}$ rRNA for $16 \mathrm{~h}$ at $60^{\circ} \mathrm{C}$ as described by Grimont and Grimont (6).

\section{RESULTS AND DISCUSSION}

Mycolic acid analysis. The results of an analysis of mycolic acid composition by the HPLC method, which has been determined to be a reliable tool for the identification of actinomycetes (1), confirmed the previous findings (15) concerning the relationship of $R$. chubuensis and Gordona species. Figure 1 shows the similar patterns of the $p$-bromophenacyl esters of the mycolic acids of $R$. chubuensis ATCC $33609^{\mathrm{T}}$ and the type strains of $G$. sputi and $G$. bronchialis; these patterns differentiated these organisms from the type strain of the type species of the genus Rhodococcus, $R$. rhodochrous, whose chromatography profile contained mycolic acids with shorter retention times.

DNA-DNA similarities. As shown in Table 1, DNA-DNA hybridization experiments revealed that there was a high level of genomic similarity between the type strains of $R$. chubuensis and $G$. sputi. We used the generally accepted criteria for defining a genomic species (23), and the level of DNA-DNA relatedness $(97 \%)$ and the difference in the thermal denaturation midpoints $\left(\Delta T_{m}, 1^{\circ} \mathrm{C}\right)$ which we determined in this study led us to consider the type strains of $R$. chubuensis and $G$. sputi members of a single species. No significant levels of DNA similarity with the other reference strains of Gordona species were observed.

Ribotyping. Ribotyping data confirmed the DNA-DNA results; the patterns for the type strains of $R$. chubuensis and $G$. sputi were similar when endonuclease $P v u$ II digestion was used (Fig. 2). In a previous study, Lasker et al. (9) characterized Rhodococcus and Gordona species by performing an rRNA gene restriction pattern analysis of the type strains. The ribotypes obtained for $R$. chubuensis ATCC $33609^{\mathrm{T}}$ and $G$. sputi ATCC $29627^{\mathrm{T}}$ by these authors with the same restriction enzyme apparently are not different from the patterns obtained in this study, and this observation allowed us to rule out any possible mislabeling or contamination in our laboratory. Thus, as defined by the type strain, we confirmed the taxonomic similarity between $R$. chubuensis and $G$. sputi.

Phenotypic characterization. The morphologic characteristics of $R$. chubuensis ATCC $33609^{\mathrm{T}}$ were similar to the characteristics given in previous descriptions (19). This organism produced dry, raised, beige colonies without mycelium, and the colonies became salmon colored after several days of culture. Strain ATCC $33609^{\mathrm{T}}$ was gram-positive and acid fast with a coryneform aspect and did not exhibit extensive branching. These characteristics are in agreement with those of Gordona species $(14,17)$. We also found that nitrate reductase

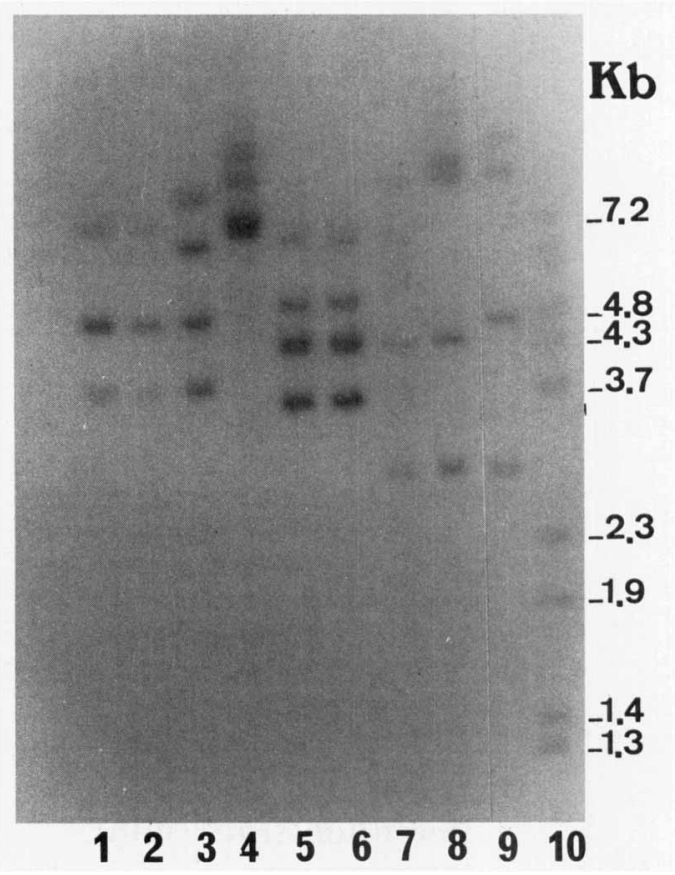

FIG. 2. rRNA gene restriction patterns after cleavage by $P v u \mathrm{II}$. Lanes 1 to $3, G$. bronchialis ATCC $25592^{\mathrm{T}}, 1828-89$, and $1829-89$, respectively; lane 4, G. rubropertincta ATCC 25593; lanes 5 and 6, $G$. terrae ATCC $25594^{\mathrm{T}}$ and $1837-89$ respectively; lanes 7 and $8, G$. sputi ATCC $29627^{\mathrm{T}}$ and 1834-89 respectively; lane 9, $R$. chubuensis ATCC $33609^{\mathrm{T}}$; lane 10, BstEII fragments of lambda DNA (sizes [in kilobases] are indicated on the right).

and urease activities are present in strain ATCC $33609^{\mathrm{T}}$ and $\beta$-galactosidase activity is not, which is a characteristic of the genus Gordona that differentiates it from the genus Nocardia (19). This strain can use citrate, $n$-butanol, monoethanolamine, mannitol, sorbitol, or 2,3-butanediol but not benzoate, inositol, or L-rhamnose as a sole carbon source. Among the biochemical data reported in the original description of $R$. chubuensis (19), differentiation of $R$. chubuensis from $G$. sputi was based primarily on the presence of $\beta$-esterase activity and Tween 80 hydrolysis in $R$. chubuensis and the ability of $R$. sputi to grow with isobutanol as a carbon source. Additional studies $(21,22)$ have modified these data and have revealed that there are no major differences between the two species in the results of these tests. Furthermore, in 1988 Zakrewska-Czerwinska et al. (24) found on the basis of DNA similarity data for the type strains that Rhodococcus obuensis could be considered a synonym of $G$. sputi. On the basis of these data and our results, below we propose an emended description of $G$. sputi (Tsukamura 1978) Stackebrandt 1989 comb. nov. Table 2 shows the major biochemical characteristics that differentiate $G$. sputi from the other Gordona species.

Emended description of Gordona sputi (Tsukamura 1978) Stackebrandt 1989 comb. nov. The salient characteristics of $G$. sputi, based on the descriptions of $R$. sputi of Tsukamura and Yano (22) and Tsukamura (18), the data of ZakrewskaCzerwinska et al. (24), and our observations, are as follows. Gram-positive, slightly acid-fast short rods or coccoid forms. Does not form spores. Mycelium is not formed. Strict aerobes. Growth occurs at 28 and $37^{\circ} \mathrm{C}$, but not at $42^{\circ} \mathrm{C}$. Colonies on Sauton agar are rough and pinkish. On Mueller-Hinton medium, dry, raised, beige colonies become salmon colored after several days of culture. Catalase positive and oxidase negative. 
TABLE 2. Characteristics used to differentiate G. sputi from other Gordona species

\begin{tabular}{lccccccc}
\hline \multirow{2}{*}{ Species } & \multicolumn{7}{c}{ Utilization of $f^{a}$} \\
\cline { 2 - 7 } & Benzoate & Inositol & Mannitol & L-Rhamnose & Sorbitol & $n$-Butanol & Monoethanolamine \\
\hline G. sputi & - & - & + & - & + & + & + \\
G. bronchialis & $\mathrm{d}$ & + & - & - & - & + & + \\
G. terrae & + & - & + & + & + & + & + \\
G. rubropertincta & + & - & + & - & + & + \\
\hline
\end{tabular}

${ }^{a}$ Data from references 21 and 22 and our observations.,$- 10 \%$ or less of the strains are positive;,$+ 90 \%$ or more of the strains are positive; d, 11 to $89 \%$ of the strains are positive. Data were obtained by using the procedure described by Tsukamura (16). The data indicate the utilization of benzoate, inositol, mannitol, L-rhamnose, sorbitol, and $n$-butanol as sole carbon sources and the utilization of monoethanolamine as a simultaneous nitrogen and carbon source.

Acid phosphatase, nitrate reductase, urease, and pyrazinamidase are produced, but $\beta$-galactosidase, benzamidase, isonicotinamidase, salicylamidase, and succinamidase are not produced. Production of $\alpha$-esterase, $\beta$-esterase, nicotinamidase, acetamidase, and allantoinase and hydrolysis of Tween 80 are variable. Glutamate and monoethanolamine are utilized by most strains as simultaneous nitrogen and carbon sources, but serine, D-glucosamine hydrochloride, benzamide, and trimethylenediamine are not utilized.

Acetate, citrate, succinate, L-malate, pyruvate, glucose, fructose, sucrose, mannitol, sorbitol, ethanol, $n$-propanol, and $n$-butanol are utilized as sole carbon sources in the presence of ammoniacal nitrogen, but benzoate, malonate, propylene glycol, 1,3-butylene glycol, 1,4-butylene glycol, inositol, and Lrhamnose are not utilized; utilization of fumarate, utilization of 2,3-butylene glycol, and utilization of isobutanol are variable. Acid is formed from glucose, D-mannose, trehalose, mannitol, and sorbitol but not from D-galactose, L-arabinose, D-xylose, L-rhamnose, and inositol. Nitrate, but not nitrite, is used as a sole nitrogen source in the presence of glycerol as a carbon source. The results of gas chromatographic and mass spectrometric analyses show that this organism has long-chain mycolic acids (numbers of carbon atoms, 56, 58, 60, 62, 64, and 66). The numbers of carbon atoms in the $\alpha$ unit are 16 and 18 , the numbers of carbon atoms in the $\beta$ unit are 40 to 48 , and the numbers of double bonds in the mycolic acids are 2 to 6 . The predominant menaquinone type is $\mathrm{MK}-9\left(\mathrm{H}_{2}\right)$, and there is a significant amount of MK- $8\left(\mathrm{H}_{2}\right),(9$ and 8 are the numbers of isoprene units in the side chain and 2 is the number of hydrogen atoms saturating the side chain). The cell wall peptidoglycan contains major amounts of meso-diaminopimelic acid, arabinose, and galactose.

The type strain is strain ATCC 29627, which was isolated from the sputum of a human patient. Strain ATCC $29627^{\mathrm{T}}$ has all of the properties described above for the species. In addition, the type strain does not produce acetamidase and allantoinase. The $\mathrm{G}+\mathrm{C}$ content of the DNA is $65.2 \mathrm{~mol} \%$, as determined by an HPLC procedure.

\section{ACKNOWLEDGMENTS}

We are grateful to P. Boiron (Institut Pasteur, Paris, France) for kindly providing reference strains and for helpful discussions. We thank C. Gallion and B. Muller for expert technical assistance.

\section{REFERENCES}

1. Butler, W. R., J. O. Kilburn, and G. P. Kubica. 1987. Highperformance liquid chromatography analysis of mycolic acids as an aid in laboratory identification of Rhodococcus and Nocardia species. J. Clin. Microbiol. 25:2126-2131.

2. Crosa, J. H., D. J. Brenner, and S. Falkow. 1973. Use of a single-strand-specific nuclease for analysis of bacterial and plasmid deoxyribonucleic acid homo- and heteroduplexes. J. Bacteriol. 115:904-911.
3. De Briel, D., F. Couderc, P. Riegel, F. Jehl, and R. Minck. 1992. High-performance liquid chromatography of corynomycolic acids as a tool in identification of Corynebacterium species and related organisms. J. Clin. Microbiol. 30:1407-1417.

4. Goodfellow, M. 1986. Genus Rhodococcus Zopf 1891, p. 14721481. In P. H. A. Sneath, N. S. Mair, M. E. Sharpe, and J. G. Holt (ed.), Bergey's manual of systematic bacteriology, vol. 2. The Williams \& Wilkins Co., Baltimore.

5. Goodfellow, M., and G. Alderson. 1977. The actinomycete genus Rhodococcus: a home for the rhodochrous complex. J. Gen. Microbiol. 100:99-122.

6. Grimont, F., and P. A. D. Grimont. 1986. Ribosomal nucleic acid gene restriction patterns as potential taxonomic tools. Ann. Inst. Pasteur Microbiol. 137B:165-175.

7. Grimont, P. A. D., M. Y. Popoff, F. Grimont, C. Coynault, and M. Lemelin. 1980. Reproductibility and correlation study of three deoxyribonucleic acid hybridization procedures. Curr. Microbiol. 4:325-330.

8. International Committee on Systematic Bacteriology. 1983. Validation of the publication of new names and new combinations effectively published outside the IJSB. List no. 12. Int. J. Syst. Bacteriol. 33:896-897.

9. Lasker, B. A., J. M. Brown, and M. M. McNeil. 1992. Identification and epidemiological typing of clinical and environmental isolates of the genus Rhodococcus with use of a digoxigenin-labeled rDNA gene probe. Clin. Infect. Dis. 15:223-233.

10. Moore, W. E. C., E. P. Cato, and L. V. H. Moore (ed.). 1985. Index of the bacterial and yeast nomenclatural changes published in the International Journal of Systematic Bacteriology since the 1980 Approved Lists of Bacterial Names (1 January 1980 to 1 January 1985). Int. J. Syst. Bacteriol. 35:382-407.

11. Moore, W. E. C., and L. V. H. Moore (ed.). 1992. Index of the bacterial and yeast nomenclatural changes published in the International Journal of Systematic Bacteriology since the 1980 Approved Lists of Bacterial Names (1 January 1980 to 1 January 1992). American Society for Microbiology, Washington, D.C.

12. Riegel, P., P. A. D. Grimont, D. de Briel, E. Ageron, F. Jehl, M. Pelegrin, H. Monteil, and R. Minck. 1992. Corynebacterium group D-2 ("Conynebacterium urealyticum") constitutes a new genomic species. Res. Microbiol. 143:307-313.

13. Skerman, V. B. D., V. McGowan, and P. H. A. Sneath (ed.). 1980. Approved lists of bacterial names. Int. J. Syst. Bacteriol. 30:225420.

14. Stackebrandt, E., J. Smida, and M. D. Collins. 1988. Evidence of phylogenetic heterogeneity within the genus Rhodococcus: revival of the genus Gordona (Tsukamura). J. Gen. Appl. Microbiol. 34:341-348.

15. Tomiyasu, I., and I. Yano. 1986. The mycolic acids and the chemotaxonomy of the genera Nocardia and Rhodococcus. J. Jpn. Soc. Actinomycetes 48:1-20.

16. Tsukamura, M. 1966. Adansonian classification of mycobacteria. J. Gen. Microbiol. 45:153-273.

17. Tsukamura, M. 1971. Proposal of a new genus, Gordona, for slightly acid-fast organisms occurring in sputa of patients with pulmonary disease and in soil. J. Gen. Microbiol. 68:15-24.

18. Tsukamura, M. 1978. Numerical classification of Rhodococcus (formerly Gordona) organisms recently isolated from sputa of 
patients: description of Rhodococcus sputi Tsukamura sp. nov. Int. J. Syst. Bacteriol. 28:169-181.

19. Tsukamura, M. 1982. Numerical analysis of the taxonomy of nocardiae and rhodococci. Division of Nocardia asteroides sensu stricto into two species and descriptions of Nocardia paratuberculosis sp. nov. Tsukamura (formerly the Kyoto-I group of Tsukamura), Nocardia nova sp. nov. Tsukamura, Rhodococcus aichiensis sp. nov. Tsukamura, Rhodococcus chubuensis sp. nov. Tsukamura, and Rhodococcus obuensis sp. nov. Tsukamura. Microbiol. Immunol. 26:1101-1119.

20. Tsukamura, M. 1991. Some addenda on the species Gordona sputi (Tsukamura 1978) Stackebrandt et al. 1989 comb. nov. Int. J. Syst. Bacteriol. 41:569-570.

21. Tsukamura, M., K. Hikosaka, K. Nishimura, and S. Hara. 1988. Severe progressive subcutaneous abscesses and necrotizing teno- synovitis caused by Rhodococcus aurantiacus. J. Clin. Microbiol. 26:201-205.

22. Tsukamura, M., and I. Yano. 1985. Rhodococcus sputi sp. nov., nom. rev., and Rhodococcus aurantiacus sp. nov., nom. rev. Int. J. Syst. Bacteriol. 35:364-368.

23. Wayne, L. G., D. J. Brenner, R. R. Colwell, P. A. D. Grimont, O. Kandler, M. I. Krichevsky, L. H. Moore, W. E. C. Moore, R. G. E. Murray, E. Stackebrandt, M. P. Starr, and H. G. Trüper. 1987. Report of the Ad Hoc Committee on Reconciliation of Approaches to Bacterial Systematics. Int. J. Syst. Bacteriol. 37:463464.

24. Zakrewska-Czerwinska, J., M. Mordarski, and M. Goodfellow. 1988. DNA base-composition and homology values in the classification of some Rhodococcus species. J. Gen. Microbiol. 134: $2807-2813$. 